\title{
3 Research Suare \\ The Effect of Pre-treatment Methods on Membrane Flux, COD, and Total Phenol Removal Efficiencies for Membrane Treatment of Pistachio Wastewater
}

\section{Yasin Ozay}

Mersin University: Mersin Universitesi

Nadir Dizge ( $\square$ nadirdizge@gmail.com )

Mersin University: Mersin Universitesi

\section{Research Article}

Keywords: Pre-treatment methods, COD removal, total phenol removal, membrane treatment, pistachio wastewater

Posted Date: October 27th, 2021

DOI: https://doi.org/10.21203/rs.3.rs-881003/v1

License: (c) (i) This work is licensed under a Creative Commons Attribution 4.0 International License.

Read Full License

Version of Record: A version of this preprint was published at Journal of Environmental Management on May 1st, 2022. See the published version at https://doi.org/10.1016/j.jenvman.2022.114762. 


\section{Abstract}

In this study, the effect of pre-treatment methods was investigated for membrane treatment of pistachio wastewater. Chemical coagulation, electrocoagulation, and electrooxidation processes were tested as the pretreatment methods to understand the effect of pretreatment on membrane performance. Alum $\left(\mathrm{Al}_{2}\left(\mathrm{SO}_{4}\right)_{3} \cdot 18 \mathrm{H}_{2} \mathrm{O}\right)$, iron (III) chloride $\left(\mathrm{FeCl}_{3} \cdot 6 \mathrm{H}_{2} \mathrm{O}\right)$ and iron(II) sulfate $\left(\mathrm{Fe}\left(\mathrm{SO}_{4}\right) \cdot 7 \mathrm{H}_{2} \mathrm{O}\right)$ were used as coagulant and anionic polyelectrolyte was used as flocculants. Al-Al and Fe-Fe electrode pairs were used in the electrocoagulation experiments while platinum, boron doped diamond, and graphite were used in the electrooxidation experiments. UP150, NF270, and NF90 were used as the membranes. Chemical oxygen demand (COD) and total phenol removal efficiencies from wastewater were determined by considering membrane flux.

\section{Introduction}

The importance of water, which is one of the most basic necessities of life on earth, continues to increase due to population growth, climate change, urbanization, and the spread of irrigated agriculture (Kılıç, 2020). Especially in some countries and regions, the scarcity of clean water resources is a factor preventing human activities and economic development (Boretti and Rosa, 2019). In the 2019 and 2020 reports of the World Economic Forum, water scarcity was stated as one of the biggest global risks in terms of potential impact for the next 10 years (Marsh and McLennan, 2020) For this reason, it is of great importance to treat and reuse the wastewater generated after use for human consumption and after industrial activities.

Treatment and reuse of industrial wastewater has become a necessity due to depletion of water resources. Pistachio processing plants are also one of the industries with intense water consumption and high pollution. Pistachio, which has an important place among agricultural products due to its economic value, is from the Pistacia type and it is a nutrient-rich product (D'Evoli et al. 2015). Turkey is known as the third-largest country for pistachio production after Iran and the United States of America. Turkey on average, produces $13 \%$ of world pistachio production (Salvador et al., 2020). The pistachio tree, which needs special climatic conditions, is mainly grown in the Southeastern Anatolia region in Turkey. After the harvest, the soft organic hull around the pistachios is softened with water and separated from the pistachio. During this process, 8-10 L of water is used for $1 \mathrm{~kg}$ of pistachios. Pistachio processing plant wastewater (PPW), which contains high chemical oxygen demand (COD), total phenol, and turbidity, is mostly discharged to the receiving environment without any treatment, causing damage to terrestrial and aquatic ecosystems (Bayar et. al. 2014; Güçlü, 2015). Considering the production data in Turkey, this situation necessitates the treatment of approximately $850,000 \mathrm{~m}^{3}$ of wastewater from pistachio processing plants per year.

In recent years, electrochemical treatment methods have been proposed for the treatment of wastewater containing toxic organic and inorganic substances that cannot be treated with conventional treatment methods (Fernandes et. al. 2015; Garcia-Rodriguez et. al. 2020). However, electrochemical treatment 
methods may not be sufficient alone in water recovery. Water recovery from wastewater is an important opportunity to combat water scarcity problems in the coming years. Therefore, membrane processes are a process that is becoming more popular day by day for water recovery from pre-treated or untreated wastewater (Ezugbe and Sudesh Rathilal, 2020). However, membrane fouling is one of the issues that stand in front of the wide usage area of membranes and await solutions. Suspended solids, microbes, organic materials etc. in wastewater cause membrane fouling when they are deposited on the membrane surface or within the membrane pores. Fouling causes decrease of permeate flux and increase of backwash frequency (Speth et. al. 1998). Membrane cleaning is a way of to control membrane fouling. Membrane cleaning can be classified largely as physical, chemical, physico-chemical, or biological/biochemical (Lin et. al. 2010; Wang et. al. 2014). Additionally, pretreatment is another method to protect membrane surface against fouling in membrane processes. Pretreatments are both reduce membrane fouling and energy utilization. Wastewater pretreatment processes change the physical, chemical, or biological properties of wastewater and it cause membrane separation more efficient (Huang et. al. 2009).

Various pre-treatment processes have been applied in membrane application in wastewater treatment until today. For example, a pilot scale application supported by clariflocculation and ozonization was applied using different membrane technologies for textile wastewater reuse. Two different case studies were evaluated in the study. In the first case study, MF membrane was placed upstream a NF process to treat a secondary effluent coming from a biological activated plant. In the second case study, several pretreatment methods such as clarification, sand filtration, and ozonization were placed for a UF treatment. The most interesting experimental results were obtained from the treatment of wastewater coming directly from the carbonising process (Marcucci et. al. 2002).

According to the literature, studies on the treatment of pistachio wastewater are few and still not at sufficient levels. In this study, the effect of pre-treatment methods was investigated for membrane treatment of pistachio wastewater. Chemical coagulation, electrocoagulation, and electrooxidation processes were tested as the pretreatment methods to understand the effect of pretreatment on membrane performance. Chemical oxygen demand (COD) and total phenol removal efficiencies from wastewater were determined by considering membrane flux. To the best of our knowledge, no study in which wastewater was treated with a membrane process was found.

\section{Materials And Methods}

\subsection{Chemical coagulation experiments}

Chemical coagulation experiments were carried out with the Mtops SF4 brand multi-mechanical mixer (jar test) setup. The device can be controlled digitally with a total mixing capacity of $2000 \mathrm{~mL}$ and a mixing speed of 20-300 rpm. Alum $\left(\mathrm{Al}_{2}\left(\mathrm{SO}_{4}\right)_{3} \cdot 18 \mathrm{H}_{2} \mathrm{O}\right)$, iron (III) chloride $\left(\mathrm{FeCl}_{3} \cdot 6 \mathrm{H}_{2} \mathrm{O}\right)$ and iron(II) sulfate $\left(\mathrm{Fe}\left(\mathrm{SO}_{4}\right) \cdot 7 \mathrm{H}_{2} \mathrm{O}\right)$ were used as coagulants and anionic polyelectrolyte was used as flocculent. pH of the solution was adjusted with $1 \mathrm{M} \mathrm{NaOH}$ or $1 \mathrm{M} \mathrm{HCl}$ solutions. 
Chemical coagulation experiments were carried out in a jar test setup with a working volume of $250 \mathrm{~mL}$ at room temperature $\left(25 \pm 1^{\circ} \mathrm{C}\right)$. Experimental plan was applied as 5 min of rapid mixing at $100 \mathrm{rpm}$ mixing speed, $2 \mathrm{~mL} / \mathrm{L}$ flocculent addition, then 25 min of slow mixing at $50 \mathrm{rpm}$ mixing speed and 30 min of settling. COD and total phenol analyzes were performed for the samples taken at the specified times. In order to decide the appropriate $\mathrm{pH}$ value, the coagulant dosage was kept constant at $500 \mathrm{mg} / \mathrm{L}$, four different $\mathrm{pH}$ values $(4,6,8$, and 10$)$ of the wastewater were tested and then four different coagulant doses $(500,1000,2000$, and $4000 \mathrm{mg} / \mathrm{L})$ were optimized at the $\mathrm{pH}$ values supplied the highest removal efficiency.

\subsection{Electrochemical experiments}

Electrocoagulation and electrooxidation experiments were carried out by a power supply (AATech ADC3303D) with 0-30 V output voltage and 0-5 A output current. The mixing of the wastewater in the borosilicate glass reactor during the experiment was provided by magnetic stirrer (Wisd MSH-20A). Iron and aluminum electrodes used in the electrochemical experiments were obtained from an industrial zone in Mersin. However, boron doped diamond (BDD), platinum, and graphite electrodes were obtained commercially.

Electrocoagulation and electrooxidation experiments were carried out in a $500 \mathrm{~mL}$ borosilicate glass reactor with $250 \mathrm{~mL}$ working volume and $300 \mathrm{rpm}$ constant stirring speed under room temperature conditions $\left(25 \pm 1^{\circ} \mathrm{C}\right)$. Aluminum $(6 \mathrm{~cm}$ wide $\times 4 \mathrm{~cm}$ high $\times 1 \mathrm{~mm}$ thick $)$ and iron $(5 \mathrm{~cm} \mathrm{wide} \times 4 \mathrm{~cm} \mathrm{high} \times$ $1 \mathrm{~mm}$ thick) was used as anode and cathode electrode pairs for electrocoagulation experiments. Platinum ( $4 \mathrm{~cm}$ wide $\times 7 \mathrm{~cm}$ height $\times 1 \mathrm{~mm}$ thick), boron doped diamond $(6 \mathrm{~cm}$ width $\times 7 \mathrm{~cm}$ height $\times 1$ $\mathrm{mm}$ thickness), and graphite $(2 \mathrm{~cm}$ width $\times 6 \mathrm{~cm}$ height $\times 1 \mathrm{~mm}$ thickness) were used as anode material while platinum was used as cathode material for electrooxidation experiments. In electrocoagulation and electrooxidation experiments, firstly, 50, 100, and $200 \mathrm{~A} / \mathrm{m}^{2}$ current densities were studied by carrying out the original $\mathrm{pH}$ value of the wastewater with the distance between the electrodes $2 \mathrm{~cm}$ and the total reaction time $180 \mathrm{~min}$. The samples were taken from the reaction medium at the specified times $(0,15$, $30,45,60,90,120,180 \mathrm{~min})$ and COD, total phenol, and chloride ( $\left.\mathrm{Cl}^{-}\right)$analyzes were performed. Afterwards, pH optimization (4, 7, and 10) was carried out at the constant current density values where the highest removal efficiency was obtained. The electrodes, which were weighed before the electrocoagulation experiments, were kept in the acidic washing solution for 5 min, washed with distilled water, dried in an oven at $105^{\circ} \mathrm{C}$, and weighed again.

\subsection{Membrane experiments}

For the membrane experiments, a stainless steel membrane filtration device (Sterlitech HP4750 brand) with a working volume of $300 \mathrm{~mL}$ and an effective filtration area of $14.6 \mathrm{~cm}^{2}$ was used with maximum working pressure of 69 bar. Nitrogen $\left(\mathrm{N}_{2}\right)$ gas was used as the driving force in all experiments.

Continuous mixing of the feed stream was ensured by a magnetic stirrer inside the reactor. The permeate 
flux was monitored instantaneously by connecting the precision balance (And FZ-3000i brand) to the computer with the help of RS-COM connection.

After pretreatment of PPW with chemical coagulation, electrocoagulation, and electrooxidation processes, water recovery performance with membrane processes was investigated by commercially purchased membranes. The general properties of the membranes used in the study are presented in Table 1. First, deionized water was filtered through the membranes for $30 \mathrm{~min}$ at different operating pressures.

Afterwards, raw wastewater and pre-treated wastewater were fed into the system. COD and total phenol analyzes were performed for the inlet and outlet samples. The flux values obtained from the membranes were calculated using equation 1.

$\operatorname{Flux}\left(J_{w}\right)=\frac{\Delta V}{\Delta x \Delta t}$

$J_{w}:$ Flux $\left(L / m^{2} . h\right) ; \Delta V$ : Amount of permeate sample collected over a given period of time $(\Delta t, h)(L), A:$ Membrane area used for filtration $\left(\mathrm{m}^{2}\right)$.

Table 1. General properties of the membranes used in the study

\begin{tabular}{|c|c|c|c|c|c|c|}
\hline Membrane & Material & $\begin{array}{l}\text { Max. } \\
\text { temperature } \\
\left({ }^{\circ} \mathrm{C}\right)\end{array}$ & $\mathrm{pH}$ & $\begin{array}{l}\text { Pore size } \\
\text { (Da) }\end{array}$ & Flux & Firm \\
\hline UP150 & $\begin{array}{l}\text { Polietersülfon } \\
\text { (PES) }\end{array}$ & 95 & $\begin{array}{l}0- \\
14\end{array}$ & $\sim 150.000$ & $\begin{array}{l}<570 \text { LMH/ } \\
2 \text { bar }\end{array}$ & $\begin{array}{l}\text { Microdyn } \\
\text { Nadir }^{\mathrm{TM}}\end{array}$ \\
\hline NF270 & $\begin{array}{l}\text { Poliamid } \\
\text { (PA) }\end{array}$ & 45 & $\begin{array}{l}2- \\
11\end{array}$ & $\sim 150-340$ & $\begin{array}{l}\text { 122-167 LMH/ } \\
8,8 \text { bar }\end{array}$ & $\begin{array}{l}\text { DOW } \\
\text { Filmtec }\end{array}$ \\
\hline NF90 & $\begin{array}{l}\text { Poliamid } \\
\text { (PA) }\end{array}$ & 45 & $\begin{array}{l}2- \\
11\end{array}$ & 90-180 & $\begin{array}{l}\text { 78-102 LMH/ } \\
\text { 8,8 bar }\end{array}$ & $\begin{array}{l}\text { DOW } \\
\text { Filmtec }\end{array}$ \\
\hline
\end{tabular}

\section{Results And Discussion}

\subsection{Chemical coagulation experiments}

\subsubsection{The effect of solution pH on COD and total phenol removal efficiency}

It is well known that solution $\mathrm{pH}$ is very importat for coagulant/flocculation applications. Coagulants used to separate colloids from water form ions depending on the $\mathrm{pH}$ of the solution. $\mathrm{Low} \mathrm{pH}$ values can prevent colloids coming together, while high pH values can cause colloids to disperse (Sun et. al. 2019; Dotto et. al. 2019). In this study, the effect of solution pH was investigated on COD and total phenol 
removal efficiencies using different type of coagulants such as aluminum sulphate $\left(\mathrm{Al}_{2}\left(\mathrm{SO}_{4}\right)_{3} \cdot 18 \mathrm{H}_{2} \mathrm{O}\right)$, iron(III) chloride $\left(\mathrm{FeCl}_{3} \cdot 6 \mathrm{H}_{2} \mathrm{O}\right)$, and iron(II) sulphate $\left(\mathrm{Fe}\left(\mathrm{SO}_{4}\right) \cdot 7 \mathrm{H}_{2} \mathrm{O}\right)$. Anionic polyelectrolyte was used as the flocculant. The results are presented in Fig. 1. The highest COD removal efficiency was determined as $39.5 \%$ for $\mathrm{Al}_{2}\left(\mathrm{SO}_{4}\right)_{3} \cdot 18 \mathrm{H}_{2} \mathrm{O}$ when the wastewater $\mathrm{pH}$ value was 8.0 . However, the highest $\mathrm{COD}$ removal efficiencies were $38.8 \%$ and $35.4 \%$ for $\mathrm{FeCl}_{3} \cdot 6 \mathrm{H}_{2} \mathrm{O}$ and $\mathrm{Fe}\left(\mathrm{SO}_{4}\right) .7 \mathrm{H}_{2} \mathrm{O}$ when the wastewater $\mathrm{pH}$ was 6.0, respectively. The lower removal efficiencies were obtained $\mathrm{pH}$ outside of this range (Fig. 1A).

The highest total phenol removal efficiency was obtained for $54.5 \%$ for $\mathrm{Al}_{2}\left(\mathrm{SO}_{4}\right)_{3} \cdot 18 \mathrm{H}_{2} \mathrm{O}$ when the wastewater $\mathrm{pH}$ value was 10 . However, the highest total phenol removal efficiencies were obtined as $57.1 \%$ for $\mathrm{FeCl}_{3} \cdot 6 \mathrm{H}_{2} \mathrm{O}$ at $\mathrm{pH} 8$ and $52.1 \%$ for $\mathrm{Fe}\left(\mathrm{SO}_{4}\right) \cdot 7 \mathrm{H}_{2} \mathrm{O}$ at $\mathrm{pH}$ 6.0. The lowest removal efficiencies were obtained at $\mathrm{pH} 4.0$ (Fig. 1B). When the dissolution diagram of aluminium and iron salts is examined depending on the ambient $\mathrm{pH}$, it is mostly in the form of $\mathrm{Al}(\mathrm{OH})_{3}$ in the $\mathrm{pH}$ range of 6.5 and 8.0 (Jiang et. al. 2002). The results obtained in this study support the high COD and total phenol removal efficiencies detected in these $\mathrm{pH}$ ranges.

\subsubsection{The effect of coagulant amount on COD and total phenol removal efficiency}

$\mathrm{Al}(\mathrm{OH})_{3}$ present in the solution in sufficient quantity comes together with the colloidal particles in the water and neutralizes their charge and flocculation occurs. The presence of an overdose of $\mathrm{Al}(\mathrm{OH})_{3}$, $\mathrm{Fe}(\mathrm{OH})_{2}$, and $\mathrm{Fe}(\mathrm{OH})_{3}$ in the solution reverses the neutralized charge and causes deflocculating (Malik, 2018). For this reason, it is extremely important to determine the optimum dosage of the coagulant both in terms of obtaining high removal efficiencies and cost. The $\mathrm{pH}$ values at which the highest COD removal efficiencies obtained were accepted as optimum $\mathrm{pH}$ value and four different concentrations (500, 1000,2000 , and $4000 \mathrm{mg} / \mathrm{L}$ ) were tested for coagulant amount optimization. The results are presented in Fig. 2. The highest COD removal efficiency was determined as $44.9 \%$ and $36.7 \%$ for $\mathrm{Al}_{2}\left(\mathrm{SO}_{4}\right)_{3} .18 \mathrm{H}_{2} \mathrm{O}$ and $\mathrm{Fe}\left(\mathrm{SO}_{4}\right) \cdot 7 \mathrm{H}_{2} \mathrm{O}$ at $1000 \mathrm{mg} / \mathrm{L}$ and $42.9 \%$ for $\mathrm{FeCl}_{3} \cdot 6 \mathrm{H}_{2} \mathrm{O}$ at $4000 \mathrm{mg} / \mathrm{L}$ coagulant amount, respectively (Fig. 2A).

The highest total phenol removal efficiency was determined as $54.4 \%, 62.9 \%$, and $62.5 \%$ at $500 \mathrm{mg} / \mathrm{L}$, $1000 \mathrm{mg} / \mathrm{L}$, and $4000 \mathrm{mg} / \mathrm{L}$ for $\mathrm{Al}_{2}\left(\mathrm{SO}_{4}\right)_{3} \cdot 18 \mathrm{H}_{2} \mathrm{O}, \mathrm{Fe}\left(\mathrm{SO}_{4}\right) \cdot 7 \mathrm{H}_{2} \mathrm{O}$, and $\mathrm{FeCl}_{3} \cdot 6 \mathrm{H}_{2} \mathrm{O}$ coagulant amount, respectively (Fig. 2B).

Real textile wastewater was treated by combined chemical coagulation, electrocoagulation, and adsorption process (Bazrafshan et al. 2015). The chemical coagulation process showed $40 \%$ of COD using $30 \mathrm{mg} / \mathrm{L}$ PAC concentration at initial pH of 7.6. In another study, Fenton's process, coagulation process, and the combination of Fenton's process with ultrasonic irradiation was investigated for pistachio processing wastewater treatment (Demir and Rastgeldi, 2018). It was reported that the optimum COD removal efficiency was achieved $60 \%$ and $45 \%$ for $\mathrm{FeCl}_{3}$ dosage of $2000 \mathrm{mg} / \mathrm{L}$ and $\mathrm{Al}_{2}\left(\mathrm{SO}_{4}\right)_{3}$ dosage of $3000 \mathrm{mg} / \mathrm{L}$, respectively, at initial $\mathrm{pH}$ of 6.0. PPW was also treated by chemical treatment 
studies using montmorillonite clay, $\mathrm{AlCl}_{3}, \mathrm{Al}_{2}\left(\mathrm{SO}_{4}\right)_{3}, \mathrm{Fe}_{2}\left(\mathrm{SO}_{4}\right)_{3}$, and $\mathrm{FeCl}_{3}$. The results showed that $\mathrm{AlCl}_{3}$ supplied the highest COD (65.8\%) and total phenol (85.5\%) removal efficiency at pH 6.5 and $1 \mathrm{~g} / \mathrm{L}$ coagulant dosage.

\subsection{Electrocoagulation experiments}

\subsubsection{The effect of current density on COD and total phenol removal efficiency}

The effect of current density $\left(50,100\right.$, and $\left.200 \mathrm{~A} / \mathrm{m}^{2}\right)$ depending on time was investigated on COD and total phenol removal efficiencies using iron and aluminum electrode pairs in the batch reactor. The experiments were carried out at the original $\mathrm{pH}$ value (4.3) of the wastewater and the distance between the electrodes was $2 \mathrm{~cm}$. The initial pH optimization of the wastewater was carried out by accepting the current density value of the experiment with the highest COD removal efficiency as optimum. The results are presented in Fig. 3. When aluminum electrodes were used, the highest COD and total phenol removal efficiencies were determined as $63.9 \%$ (Fig. 3A) and $72.4 \%$ (Fig. 3B), respectively, where the current density was $100 \mathrm{~A} / \mathrm{m}^{2}$. It was observed that while the current density was $200 \mathrm{~A} / \mathrm{m}^{2}$, the COD and total phenol removal efficiencies were $63.3 \%$ and $69.4 \%$, respectively. There was a decrease in the removal efficiencies compared to $100 \mathrm{~A} / \mathrm{m}^{2}$. The reason could be explained as $\mathrm{Al}^{3+}$ ions was released more into the solution with the increase of current density and it caused the colloidal fragments to disperse.

When iron electrodes were used, the highest COD and total phenol removal efficiency were found to be $56.1 \%$ (Fig. 3C) and 70.9\% (Fig. 3D), respectively, where the current density was $50 \mathrm{~A} / \mathrm{m}^{2}$. The lower COD and total phenol removal efficiencies were obtained at the current density of $100 \mathrm{~A} / \mathrm{m}^{2}$ and $200 \mathrm{~A} / \mathrm{m}^{2}$.

\subsubsection{The effect of solution $\mathrm{pH}$ on $\mathrm{COD}$ and total phenol removal efficiency}

In the experiments carried out with aluminum electrodes at a current density of $100 \mathrm{~A} / \mathrm{m}^{2}$, the highest COD removal efficiency was $63.9 \%$ where the initial pH of the wastewater was 4.0 (Fig. 4A). The highest total phenol removal efficiency was $74.2 \%$ at pH 7.0 (Fig. 4B).

In the experiments carried out with iron electrodes at a current density of $50 \mathrm{~A} / \mathrm{m}^{2}$, the highest COD removal efficiency was $56.1 \%$ at pH 4.0 (Fig. $4 \mathrm{C}$ ) and the highest total phenol removal efficiency was $76.4 \%$ at $\mathrm{pH} 10$ (Fig. 4D).

As it is known from the previous study, the $\mathrm{pH}$ of the wastewater solution increases throughout the process in the electrocoagulation process. The reason can be explained by the accumulation of $\mathrm{OH}^{-}$ions in the wastewater as a result of the reduction reactions occurring at the cathode (Elazzouzi et. al. 2017). These results are in agreement with studies in which the $\mathrm{pH}$ of the solution medium generally rises during the electrochemical treatment (Kobya et. al. 2003; Kim et. al. 2016). In the electrocoagulation 
experiments, the highest COD removal efficiency was obtained for Al-Al and Fe-Fe electrode pairs in the experimental condition where the initial $\mathrm{pH}$ value of the wastewater was 4.0. With the increase of the initial $\mathrm{pH}$ value of the wastewater, a decrease was observed in the COD removal efficiencies. When our results were compared with the studies in the literature, similar results were obtained. Bayar et al. reported that the COD removal efficiency decreased from 49.8-25.7\% when the initial pH value increased from 4.0 to 8.0 in the treatment of PPW using Al-Al electrodes by electrocoagulation process (Bayar et. al. 2014). In another study, aluminum electrodes were used in the treatment of PPW with the electrocoagulation process and it was reported that the COD removal efficiency decreased with the increase in the initial $\mathrm{pH}$ value of the wastewater. The highest COD removal efficiency was obtained as $57.4 \%$ in the optimum condition where the initial pH value of the wastewater was 6.0 (Güçlü, 2015).

\subsection{Electrooxidation experiments}

\subsubsection{The effect of current density on COD and total phenol removal efficiency}

A wide variety of electrodes such as carbon, graphite, gold, platinum, metal oxide, mixed metal oxide, boron doped diamond are used in the treatment of wastewater with the electrooxidation process. The costs of these electrodes, whose catalytic activities depend not only on their composition but also on their production method, can be quite high (Shestakova and Sillanpää, 2017). In the electrooxidation experiments, platinum electrode was used as cathode material whereas boron doped diamond and graphite electrodes were used as anode material. First, the current density $\left(50,100\right.$, and $\left.200 \mathrm{~A} / \mathrm{m}^{2}\right)$ was investigated the effects on removal efficiencies depending on time at the original $\mathrm{pH}$ value of the wastewater. Second, the current density value of the experiment with the highest COD removal efficiency was accepted as optimum, and the initial pH optimization of the wastewater was carried out.

In the electrooxidation experiments carried out using boron-doped diamond (BDD) as the anode material and platinum electrode as the cathode material at the original $\mathrm{pH}$ value of the wastewater, COD removal efficiencies were $42.2 \%, 56.8 \%$, and $61.2 \%$ for current density of $50 \mathrm{~A} / \mathrm{m}^{2}, 100 \mathrm{~A} / \mathrm{m}^{2}$, and $200 \mathrm{~A} / \mathrm{m}^{2}$, respectively (Fig. 5A). However, total phenol removal efficiencies were $38.9 \%, 57.1 \%$, and $76.8 \%$ for current density of $50 \mathrm{~A} / \mathrm{m}^{2}, 100 \mathrm{~A} / \mathrm{m}^{2}$, and $200 \mathrm{~A} / \mathrm{m}^{2}$, respectively (Fig. 5B). COD and total phenol removal efficiencies increased with the increase in current density. While the oxidation of pollutants in the wastewater occurs directly or indirectly in the presence of chloride ions $\left(\mathrm{Cl}^{-}\right)$, anodic chlorine gas $\left(\mathrm{Cl}_{2}\right)$ reacts with water and turns into derivatives such as hypochlorite $\left(\mathrm{ClO}^{-}\right)$and chlorine dioxide $\left(\mathrm{ClO}_{2}\right)$ (Santhanam et. al. 2015). $\mathrm{Cl}^{-}$concentration in the wastewater was determined as 997,798 , and 647 $\mathrm{mg} / \mathrm{L}$ for 50,100 , and $200 \mathrm{~A} / \mathrm{m}^{2}$, respectively (Fig. 5C). It is thought that pollutants in wastewater undergo more indirect oxidation in the presence of $\mathrm{Cl}^{-}$with increasing of current density. In the electrooxidation experiments carried out using graphite electrode as the anode material and platinum electrode as the cathode material at the original $\mathrm{pH}$ value of the wastewater, $\mathrm{COD}$ removal efficiencies 
were $36.8 \%, 38.1 \%$, and $42.2 \%$ for current density of $50 \mathrm{~A} / \mathrm{m}^{2}, 100 \mathrm{~A} / \mathrm{m}^{2}$, and $200 \mathrm{~A} / \mathrm{m}^{2}$, respectively (Fig. 5D). However, total phenol removal efficiencies were 55.8\%, 56.5\%, and 57.4\% for current density of $50 \mathrm{~A} / \mathrm{m}^{2}, 100 \mathrm{~A} / \mathrm{m}^{2}$, and $200 \mathrm{~A} / \mathrm{m}^{2}$, respectively (Fig. 5E). $\mathrm{Cl}^{-}$concentration in the wastewater was determined as 950, 897, and $775 \mathrm{mg} / \mathrm{L}$ for 50, 100 and $200 \mathrm{~A} / \mathrm{m}^{2}$, respectively (Fig. 5F).

The efficiencies of COD and total phenol removal in the electrooxidation process largely depend on the applied current density. In experiments where BDD and graphite electrodes were used as anode materials, it was observed that COD and total phenol removal efficiencies increased with the increase in current density. These results consistent with the studies in the literature. In a study in which boron doped diamond was used as the anode material in the treatment of landfill leachate with the electrooxidation process, it was found that COD removal efficiency increased from $68.2-92.0 \%$ with the increase of the current density from $60 \mathrm{~A} / \mathrm{m}^{2}$ to $360 \mathrm{~A} / \mathrm{m}^{2}$ (Ukundimana et. al. 2018). In the study where boron-doped diamond anode material was used in the treatment of cardboard production plant wastewater, it was reported that COD removal efficiency increased from 49.2-89.2\% with the increase of the current density from $25 \mathrm{~A} / \mathrm{m}^{2}$ to $100 \mathrm{~A} / \mathrm{m}^{2}$ (Gengec, 2017).

\subsubsection{The effect of solution $\mathrm{pH}$ on $\mathrm{COD}$ and total phenol removal efficiency}

In $\mathrm{pH}$ optimization experiments performed with a current density of $200 \mathrm{~A} / \mathrm{m}^{2}$, where the BDD-Pt electrode pairs was used and the highest COD as well as total phenol removal efficiencies were obtained as $61.2 \%$ at pH 4.0 (Fig. 6A) and 83.1\% at pH 10 (Fig. 6B), respectively. It was observed that COD removal efficiency decreased with the increase in the initial $\mathrm{pH}$ value of the wastewater, while total phenol removal efficiency reached the highest point at $\mathrm{pH} 7.0$ and then decreased slightly at $\mathrm{pH} 10$. The $\mathrm{Cl}^{-}$concentration in the wastewater was determined as 547, 752, and $598 \mathrm{mg} / \mathrm{L}$ for $\mathrm{pH} \mathrm{4,} \mathrm{7,} \mathrm{and} \mathrm{10,} \mathrm{respectively} \mathrm{(Fig.} \mathrm{6C).} \mathrm{In} \mathrm{pH}$ optimization experiments performed with a current density of $200 \mathrm{~A} / \mathrm{m}^{2}$, where graphite-Pt electrode pairs was used and the highest COD and total phenol removal efficiencies were obtained 53.4\% (Fig. 6D) and 63.0\% (Fig. 6E) for $\mathrm{pH} \mathrm{10,} \mathrm{respectively.} \mathrm{It} \mathrm{was} \mathrm{observed} \mathrm{that} \mathrm{COD} \mathrm{and} \mathrm{total} \mathrm{phenol} \mathrm{removal} \mathrm{efficiency}$ increased with the increase in the initial $\mathrm{pH}$ value of the wastewater. The $\mathrm{Cl}^{-}$concentration in the wastewater was determined as 775, 720, and $620 \mathrm{mg} / \mathrm{L}$ for $\mathrm{pH} 4.0,7.0$, and 10, respectively (Fig. 6F).

\subsection{Membrane experiments}

\subsubsection{The effect of pre-treatment method on UP150 flux}

Raw PPW and pre-treated PPW with chemical coagulation, electrocoagulation, and electrooxidation processes were progressively further treated with ultrafiltration (UP150) and nanofiltration (NF270, NF90) membranes to improve COD and total phenol removal efficiencies. The water recovery performance was investigated by calculating effluent COD and total phenol concentration, the initial and equilibrium flux values of the membranes. The structure of both NF membranes is in the form of composite polyamide 
thin film. These membranes consist of an ultra-thin polyamide barrier layer on top, a microporous polysulfone interlayer, and a polyester support structure on bottom. The NF270 membrane is a piperazine-based semi-aromatic polyamide thin-film composite, and the NF90 membrane is a completely aromatic polyamide-based thin-film composite. The water obtained from the experiments, in which maximum COD and total phenol removal efficiency was obtained after the pre-treatment processes, was first filtered through the UP150 membranes for 120 min with an operating pressure of 5 bar. Coagulant dosage and wastewater initial $\mathrm{pH}$ value conditions applied in chemical coagulation method, which is one of the pretreatment methods with optimum COD and total phenol removal efficiency, were $1000 \mathrm{mg} / \mathrm{L}$ and $\mathrm{pH} 6.0$ for $\mathrm{Fe}\left(\mathrm{SO}_{4}\right) .7 \mathrm{H}_{2} \mathrm{O}, 4000 \mathrm{mg} / \mathrm{L}$ and $\mathrm{pH} 6.0$ for $\mathrm{FeCl}_{3} .6 \mathrm{H}_{2} \mathrm{O}, 1000 \mathrm{mg} / \mathrm{L}$ and $\mathrm{pH} 8.0$ for $\mathrm{Al}_{2}\left(\mathrm{SO}_{4}\right)_{3} \cdot 18 \mathrm{H}_{2} \mathrm{O}$. The current density applied in the electrocoagulation method and the initial $\mathrm{pH}$ value of the wastewater were $100 \mathrm{~A} / \mathrm{m}^{2}$ and $\mathrm{pH} 4.0$ for Al-Al electrode pairs, $50 \mathrm{~A} / \mathrm{m}^{2}$ and $\mathrm{pH} 4.0$ for Fe-Fe electrode pairs, respectively. However, the current density applied in the electrooxidation method and the initial $\mathrm{pH}$ value of the wastewater were $200 \mathrm{~A} / \mathrm{m}^{2}$ and $\mathrm{pH} 4$ for the BDD-Pt electrode pairs, $200 \mathrm{~A} / \mathrm{m}^{2}$ and $\mathrm{pH} 10$ for the graphite-Pt electrode pairs, respectively. All water obtained after pretreatment was adjusted to $\mathrm{pH} 6$ before being fed to the UP150 membrane.

The initial and equilibrium fluxes of the raw wastewater after the UP150 membrane were 56.3 and 3.3 $\mathrm{L} / \mathrm{m}^{2} \mathrm{~h}$, respectively. $\mathrm{Fe}\left(\mathrm{SO}_{4}\right) \cdot 7 \mathrm{H}_{2} \mathrm{O}$ used in chemical coagulation process supplied the highest initial and steady-state fluxes as 132.3 and $7.5 \mathrm{~L} / \mathrm{m}^{2} \mathrm{~h}$, respectively, compared to $\mathrm{FeCl}_{3} \cdot 6 \mathrm{H}_{2} \mathrm{O}$ and $\mathrm{Al}_{2}\left(\mathrm{SO}_{4}\right)_{3} \cdot 18 \mathrm{H}_{2} \mathrm{O}$ (Fig. 7). Al-Al electrode pairs used in electrocoagulation process supplied the highest initial and steadystate fluxes as 2606.3 and $391.4 \mathrm{~L} / \mathrm{m}^{2} \mathrm{~h}$, respectively, compared to Fe-Fe electrode pairs. Moreover, BDDPt electrode pairs used in electrooxidation process supplied the highest initial and steady-state fluxes as 129 and $20.6 \mathrm{~L} / \mathrm{m}^{2} \mathrm{~h}$, respectively, compared to graphite-Pt electrode pairs. The results showed that wastewater electro-coagulated with Al-Al electrode pairs supplied the highest initial and steady-state flux values and steady-state flux value was 118 times higher than raw wastewater. The lowest initial and steady-state fluxes were obtained with wastewater subjected to electrooxidation with graphite-Pt electrode pairs. The obtained results showed that all pretreatment methods protected UP150 membrane against fouling at different rates. The reason can be explained as the removal of some of the compounds that might be contaminated the membrane surface from the wastewater with the help of mechanisms that occur in coagulation, electrocoagulation, and electrooxidation methods.

\subsubsection{The effect of pre-treatment method on NF270 and NF90 fluxes}

The permeates obtained from the raw wastewater and ultrafiltration (UP150) membrane were used as separate feed streams in the next stage of NF270 (5 bar) and NF90 (10 bar) membranes. The initial and steady-state fluxes of raw wastewater for NF270 membrane were 13.6 and $4.8 \mathrm{~L} / \mathrm{m}^{2} \mathrm{~h}$, respectively. NF270 membrane was fouled seriously and UP150 membrane was used as pre-treatment. However, the initial fluxes for UP150 + NF270 membranes were 19.0, 23.4, and $28.8 \mathrm{~L} / \mathrm{m}^{2} \mathrm{~h}$ after chemical coagulation, 
electrooxidation, and electrocoagulation, respectively. The steady-state fluxes for UP150 + NF270 membranes were $8.2,12.3$, and $16.8 \mathrm{~L} / \mathrm{m}^{2} \mathrm{~h}$ after chemical coagulation, electrooxidation, and electrocoagulation, respectively.

The initial and steady-state fluxes of raw wastewater for NF90 membrane were 5.3 and $1.2 \mathrm{~L} / \mathrm{m}^{2} \mathrm{~h}$, respectively. NF90 membrane was fouled seriously and UP150 membrane was used as pre-treatment. However, the initial fluxes for UP150 + NF90 membranes were 11.7, 17.8, and $22.2 \mathrm{~L} / \mathrm{m}^{2} \mathrm{~h}$ after chemical coagulation, electrooxidation, and electrocoagulation, respectively. The steady-state fluxes for UP150 + NF90 membranes were $2.9,7.0$, and $8.6 \mathrm{~L} / \mathrm{m}^{2} \mathrm{~h}$ after chemical coagulation, electrooxidation, and electrocoagulation, respectively.

\subsubsection{Analyses results of the membrane permeates 3.4.3.1. For UP150 membrane}

While COD and total phenol removal efficiencies in the UP150 permeate stream of raw wastewater were $42.2 \%$ and $33.3 \%$, respectively. However, COD and total phenol removal efficiencies were obtained as $62.6 \%$ and $64.0 \%$ for $\mathrm{Fe}\left(\mathrm{SO}_{4}\right) \cdot 7 \mathrm{H}_{2} \mathrm{O}, 53.7 \%$ and $70.2 \%$ for $\mathrm{FeCl}_{3} \cdot 6 \mathrm{H}_{2} \mathrm{O}$, and $49.0 \%$ and $61.6 \%$ for $\mathrm{Al}_{2}\left(\mathrm{SO}_{4}\right)_{3} \cdot 18 \mathrm{H}_{2} \mathrm{O}$ when chemical coagulation/flocculation was used as pre-treatment method (Fig. $\left.9 \mathrm{~A}\right)$. When electrocoagulation method was used, $C O D$ and total phenol removal efficiencies were obtained as $66.0 \%$ and $74.2 \%$ for Al-Al electrode pairs and $57.1 \%$ and $71.7 \%$ for Fe-Fe electrode pairs, respectively (Fig. 9B). When electrooxidation method was used, COD and total phenol removal efficiencies were determined as $68.0 \%$ and $86.6 \%$ for BDD-Pt electrode pairs and $59.2 \%$ and $78.1 \%$ for the graphite-Pt electrode pairs (Fig. 9C).

\subsubsection{For NF membranes}

COD and total phenol removal efficiencies of the raw wastewater in the permeate were obtained $80.5 \%$ and $90.6 \%$, respectively, when NF270 membrane was used. However, COD and total phenol removal efficiencies were determined as $86.4 \%$ and $100 \%$ for electrocoagulation + UP150, $89.8 \%$ and $100 \%$ for electrooxidation + UP150, 82.0\% and 92.9\% for chemical coagulation + UP150, respectively (Fig. 10A).

COD and total phenol removal efficiencies of the raw wastewater in the permeate were obtained $96.0 \%$ and $97.5 \%$, respectively, when NF90 membrane was used. However, COD and total phenol removal efficiencies were determined as $98.6 \%$ and $100 \%$ for electrocoagulation + UP150, $97.9 \%$ and $100 \%$ for electrooxidation + UP150, $96.6 \%$ and $100 \%$ for chemical coagulation + UP150, respectively (Fig. 10B). It seems that the chemical and electrochemical pre-treatment of the PPW positively affects the water recovery performance of the membrane processes in terms of both the initial and steady-state fluxes as well as COD and total phenol removal efficiencies.

\section{Conclusion}


In the pre-treatment of pistachio processing plant wastewater, electrochemical (electrocoagulation and electrooxidation) process provided higher COD and total phenol removal efficiency compared to chemical coagulation. In electrocoagulation experiments, the highest COD and total phenol removal efficiency were obtained $63.9 \%$ and $72.4 \%$, respectively, at the current density of $100 \mathrm{~A} / \mathrm{m}^{2}$ and the initial $\mathrm{pH}$ value of the wastewater of 4.3 (original pH) using Al-Al electrode pairs. In electrooxidation experiments, the highest COD and total phenol removal efficiency were obtained $61.2 \%$ and $76.8 \%$, respectively, at the current density of $200 \mathrm{~A} / \mathrm{m}^{2}$ and the initial pH value of the wastewater of 4.3 using BDD-Pt electrode pairs. These highest COD and total phenol removal efficiencies obtained during pretreatment resulted in less fouling of the membranes in the next stage of water recovery with membrane processes, resulting in higher flux values. Considering the high flux and permeate quality observed in membrane processes, it can be said that the most ideal recovery method for water recovery from PPW is filtration through UP150 and NF90 membranes after the electrocoagulation process. Thanks to the applied water recovery process, less damage will be done to the receiving environment as the wastewater is treated. In addition, groundwater and surface water resources will be protected by reusing the recovered water in the pistachio processing plant.

\section{Declarations}

- Ethical Approval: Not applicable

- Consent to Participate: Not applicable

- Consent to Publish: Not applicable

- Authors Contributions: YO carried out the methodology. ND were a major contributor in writing the manuscript. All authors read and approved the final manuscript.

- Funding: This project was supported by Mersin University of Scientific Research Council (Project Number: 2019-1-TP3-3492).

- Competing Interests: The authors declare that they have no competing interests

- Availability of data and materials: The datasets used and/or analyzed during the current study are available from the corresponding author on reasonable request

\section{References}

Bayar, S., Boncukcuoğlu, R., Yilmaz, A. E. \& Fil, B. A. Pre-Treatment of Pistachio Processing Industry Wastewaters (PPIW) by Electrocoagulation using Al Plate Electrode. Sep. Sci. Technol. 49, 1008-1018 (2014).

Bazrafshana, E., Alipoura, M.R., Mahvi, A.H., Textile wastewater treatment by application of combined chemical coagulation, electrocoagulation, and adsorption processes, Desalination and Water Treatment, 
(2015) 1-13.

Boretti, A. Rosa, L., Reassessing the projections of the World Water Development Report, npj Clean Water (2019) 1-15.

Demir, Ö., Rastgeldi, B., Treatment of the pistachio processing wastewater using Fenton's, ultrasound with Fenton's, and coagulation processes, Environment Protection Engineering, 44(1) (2018) 167-180.

D’Evoli, L., Lucarini, M., Gabrielli, P., Aguzzi, A., Lombardi-Boccia, G. Nutritional Value of Italian Pistachios from Bronte (Pistacia vera, L.), Their Nutrients, Bioactive Compounds and Antioxidant Activity, Food and Nutrition Sciences, 6 (2015) 1267-1276.

Dotto, J., Fagundes-Klen, M. R., Veit, M. T., Palácio, S. M. \& Bergamasco, R. Performance of different coagulants in the coagulation/flocculation process of textile wastewater. J. Clean. Prod. 208, 656-665 (2019).

Elazzouzi, M., Haboubi, K. \& Elyoubi, M. S. Electrocoagulation flocculation as a low-cost process for pollutants removal from urban wastewater. Chem. Eng. Res. Des. 117, 614-626 (2017).

Ezugbe, E.O. Rathilal, S., Membrane Technologies in Wastewater Treatment: A Review, Membranes 10(89) (2020) 1-28.

Fernandes, A., Pacheco, M.J., Ciríaco, L. Lopes, A., Review on the electrochemical processes for the treatment of sanitary landfill leachates: Present and future, Applied Catalysis B: Environmental, 176-177 (2015) 183-200.

Garcia-Rodriguez, O., Mousset, E., Olvera-Vargas, H., Lefebvre, O., Electrochemical treatment of highly concentrated wastewater: A review of experimental and modeling approaches from lab- to full-scale, Critical Reviews in Environmental Science and Technology, (2020) 1-70.

Gengec, E. Treatment of highly toxic cardboard plant wastewater by a combination of electrocoagulation and electrooxidation processes. Ecotoxicol. Environ. Saf. 145, 184-192 (2017).

Güçlü, D. Optimization of electrocoagulation of pistachio processing wastewaters using the response surface methodology. Desalin. Water Treat. 54, 3338-3347 (2015).

Huang, H., Schwab, K., Jacangelo, J.G., Pretreatment for Low Pressure Membranes in Water Treatment:

A Review. Environ. Sci. Technol. 43 (2009) 3011-3019.

Jiang, J. Q., Graham, N., André, C., Kelsall, G. H. \& Brandon, N. Laboratory study of electro-coagulationflotation for water treatment. Water Res. 36, 4064-4078 (2002).

Kılıç, Z., The importance of water and conscious use of water, Int J Hydro. 4(5) (2020) 239-241. 
Malik, Q. H. Performance of alum and assorted coagulants in turbidity removal of muddy water. Appl. Water Sci. 8, 1-4 (2018).

Kim, K. J. et al. Study on electrocoagulation parameters (current density, $\mathrm{pH}$, and electrode distance) for removal of fluoride from groundwater. Environ. Earth Sci. 75, 1-8 (2016).

Kobya, M., Can, O. T. \& Bayramoglu, M. Treatment of textile wastewaters by electrocoagulation using iron and aluminum electrodes. J. Hazard. Mater. 100, 163-178 (2003).

Marcucci, M. Ciardelli, G., Matteucci, A., Ranieri, L., M. Russo., Experimental campaigns on textile wastewater for reuse by means of different membrane processes, Desalination, 149 (2002) 137-143.

Marsh \& McLennan and Zurich Insurance Group, The Global Risks Report 2020 15th Edition, 2020.

Lin, J.C.T., Lee, D.J., Huang, C. Membrane Fouling Mitigation: Membrane Cleaning. Sep. Sci. Technol. 45 (2010) 858-872.

Salvador, M.D., Ojeda-Amador, R.M. Fregapane, G., Chapter 30 - Pistachio nut, its virgin oil, and their antioxidant and bioactive activities, Pathology Oxidative Stress and Dietary Antioxidants, (2020) 309-320.

Santhanam, M., Annamalai, S., Sudanthiramoorthy, S. \& Gopalakrishnan, R. A simple strategy for monitoring of aromatic degradation in a chloride mediated electrooxidation process. RSC Adv. 5, 7552875532 (2015).

Shestakova, M. \& Sillanpää, M. Electrode materials used for electrochemical oxidation of organic compounds in wastewater. Rev. Environ. Sci. Biotechnol. 16, 223-238 (2017).

Speth, T.F.; Summers, R.S.; Gusses, A.M. Nanofiltration Foulants from a Treated Surface Water. Environ. Sci. Technol. 32 (1998) 3612-3617.

Sun, H., Jiao, R., Xu, H., An, G. \& Wang, D. The influence of particle size and concentration combined with pH on coagulation mechanisms. J. Environ. Sci. (China) 82, 39-46 (2019).

Tırnık, S., Nuhoğlu, A., Kul, S., Characterization of pistachio processing industry wastewater and investigation of chemical pretreatment, Environmental Research \& Technology, 3(4) (2020) 209-216.

Ukundimana, Z., Omwene, P.I. Gengec, E., Can, O.T., Kobya, M., Electrooxidation as post treatment of ultrafiltration effluent in a landfill leachate MBR treatment plant: Effects of BDD, Pt and DSA

anode types, Electrochimica Acta 286 (2018) 252-263.

Wang, Z., Ma, J., Tang, C.Y., Kimura, K., Wang, Q., Han, X. Membrane cleaning in membrane bioreactors: A review. J. Membr. Sci. 468 (2014) 276-307. 

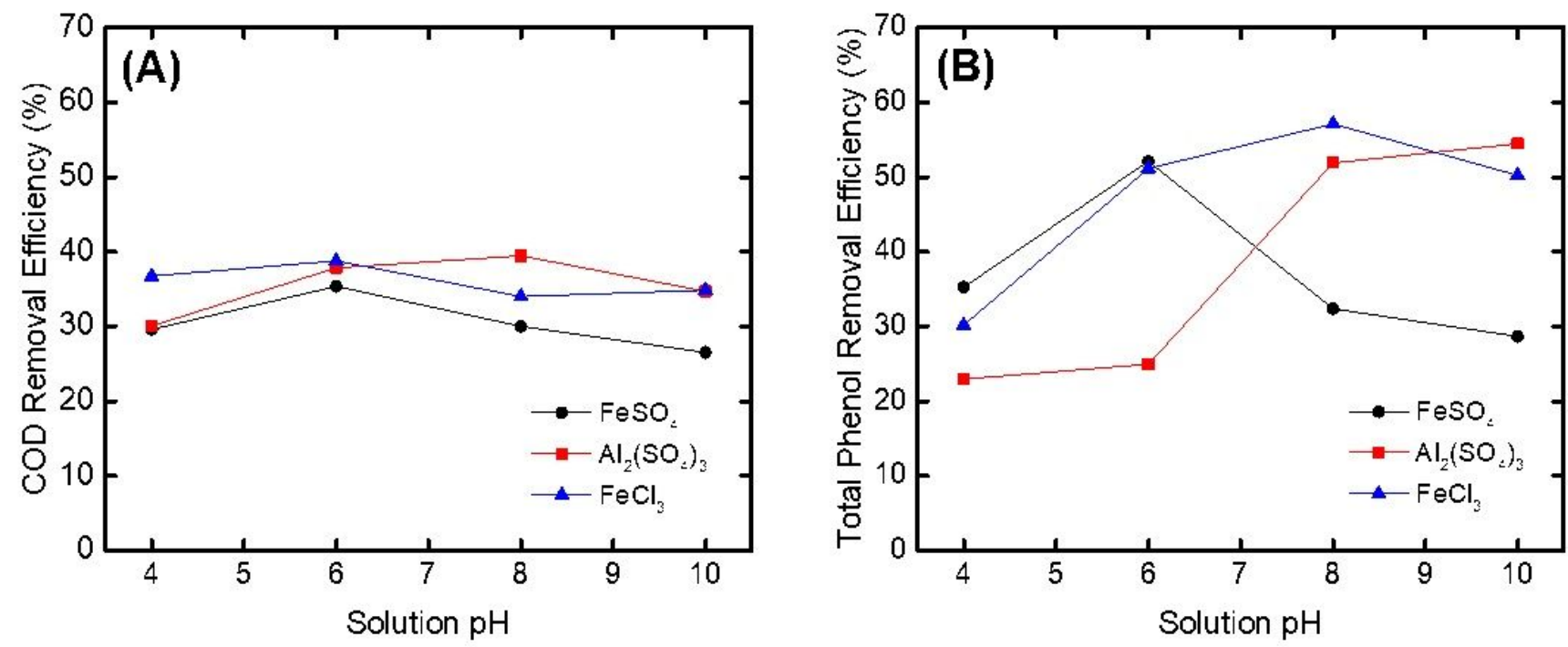

\section{Figure 1}

The effect of solution $\mathrm{pH}$ on (A) COD and (B) total phenol removal efficiencies (Experimental conditions: Influent COD: 23,520 mg/L; influent total phenol: 1,668 mg/L; coagulant amount: $500 \mathrm{mg} / \mathrm{L}$; flocculent amount: $2 \mathrm{~mL} / \mathrm{L}$; reaction volume: $250 \mathrm{~mL}$; temperature: $25 \pm 1^{\circ} \mathrm{C}$ )
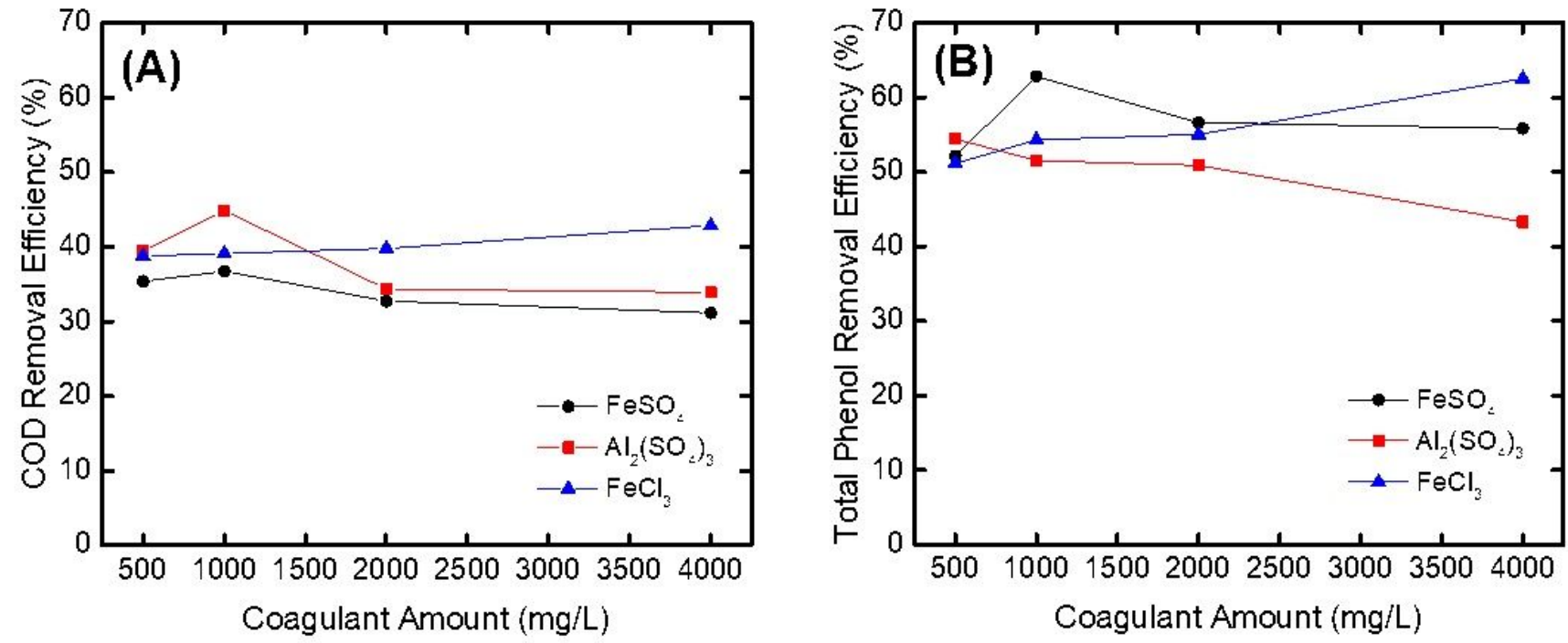

Figure 2

The effect of coagulant amount on (A) COD and (B) total phenol removal efficiencies (Experimental conditions: Influent COD: $23,520 \mathrm{mg} / \mathrm{L}$; influent total phenol: $1,668 \mathrm{mg} / \mathrm{L} ; \mathrm{pH}$ of solution: 8.0 for $\mathrm{Al} 2(\mathrm{SO} 4) 3.18 \mathrm{H} 2 \mathrm{O}, 6.0$ for $\mathrm{FeCl} 3.6 \mathrm{H} 2 \mathrm{O}$ and $\mathrm{Fe}(\mathrm{SO} 4) .7 \mathrm{H} 2 \mathrm{O}$; flocculent amount: $2 \mathrm{~mL} / \mathrm{L}$; reaction volume: $250 \mathrm{~mL}$; temperature: $25 \pm 1{ }^{\circ} \mathrm{C}$ ). 

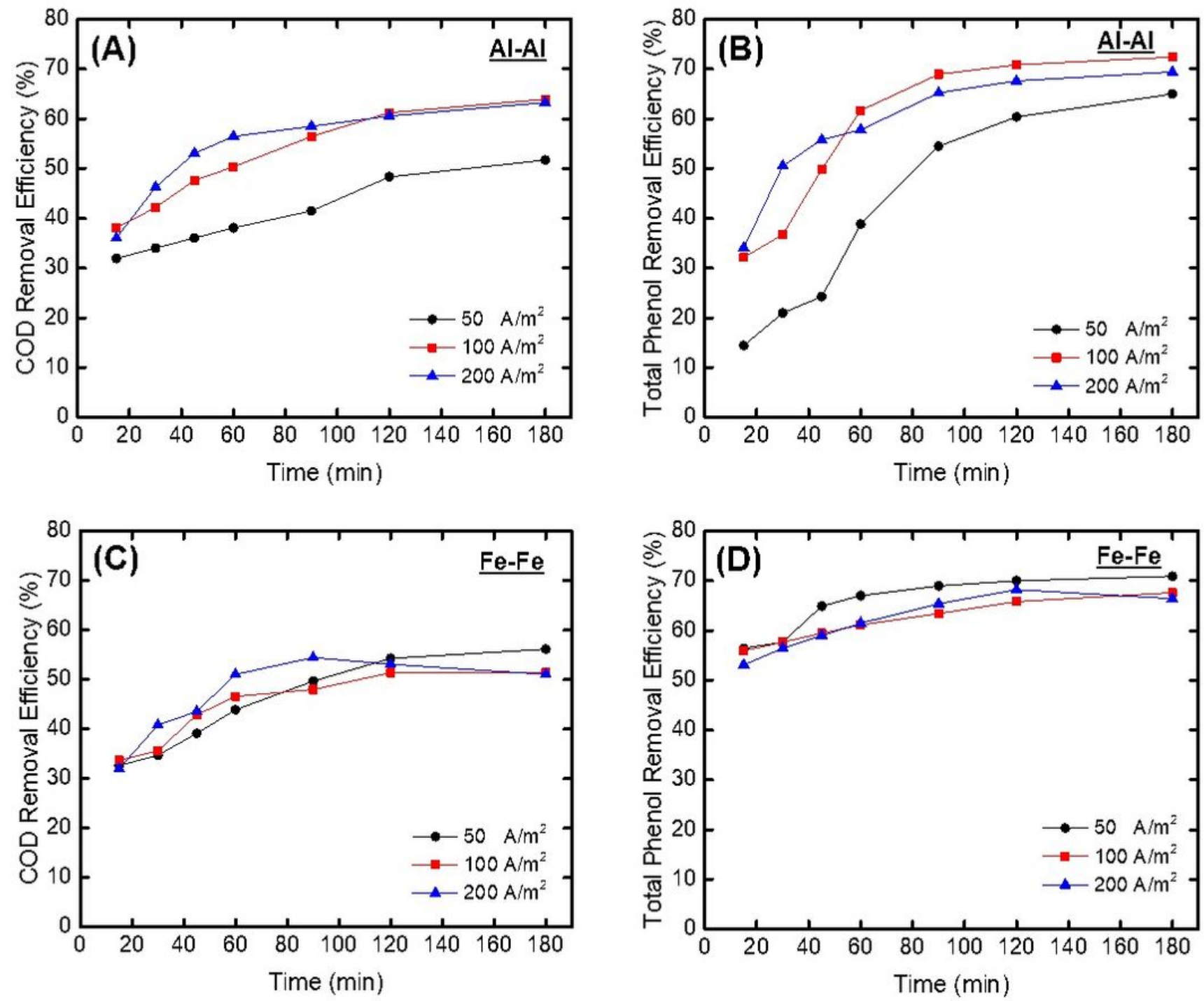

\section{Figure 3}

The effect of current density on (A) COD removal efficiency for Al-Al electrode pairs, (B) Total phenol removal efficiency for Al-Al electrode pairs, (C) COD removal efficiency for Fe-Fe electrode pairs, (D) Total phenol removal efficiency for Fe-Fe electrode pairs (Experimental conditions: initial pH: 4.3; influent COD: $23,520 \mathrm{mg} / \mathrm{L}$; influent total phenol: 1,668 mg/L; reaction volume: $250 \mathrm{~mL}$; stirring rate: $300 \mathrm{rpm}$; temperature: $25 \pm 1^{\circ} \mathrm{C}$ ). 

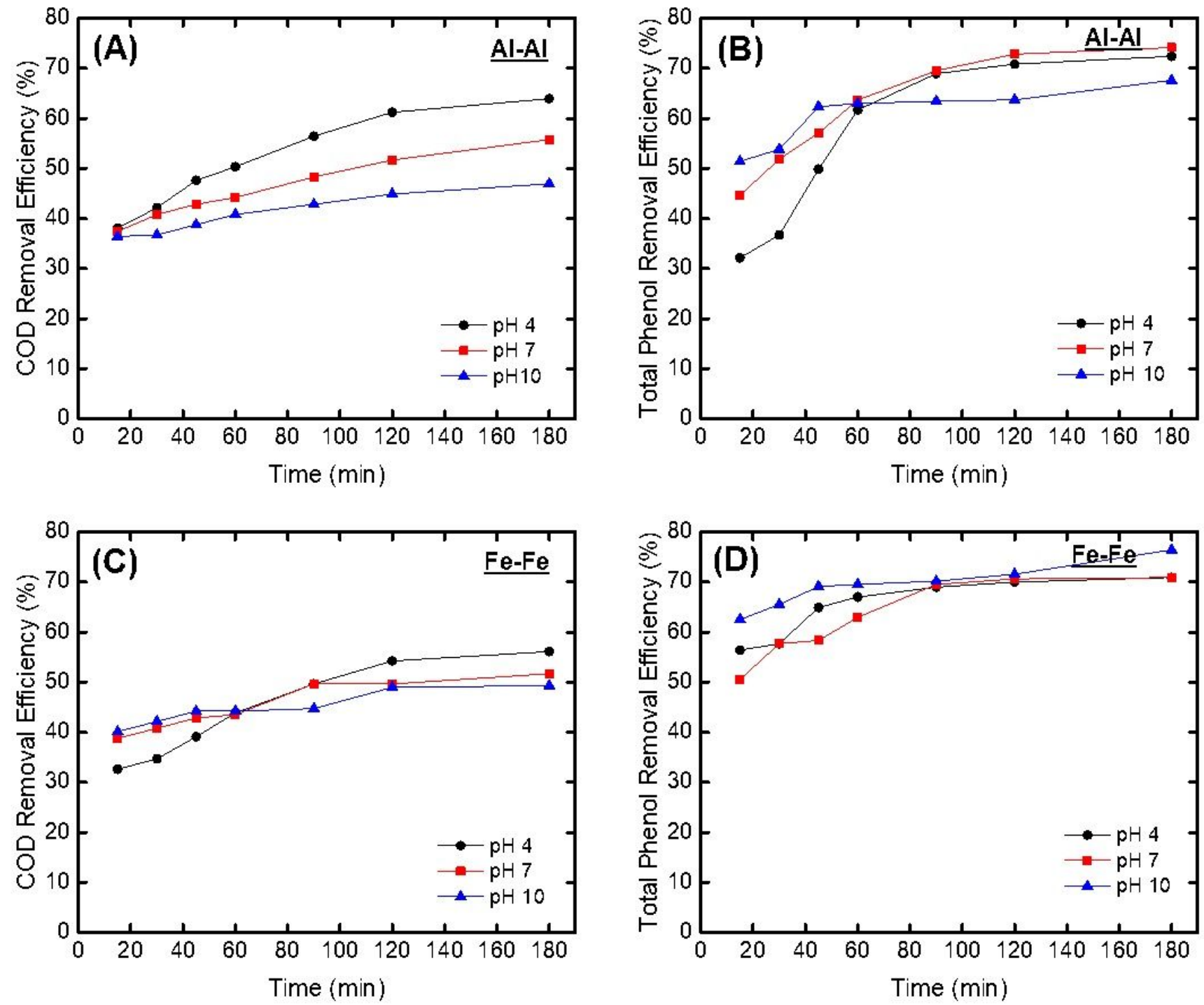

Figure 4

The effect of solution pH on (A) COD removal efficiency for Al-Al electrode pairs, (B) Total phenol removal efficiency for Al-Al electrode pairs, (C) COD removal efficiency for Fe-Fe electrode pairs, (D) Total phenol removal efficiency for Fe-Fe electrode pairs (Experimental conditions: Conductivity: $5.9 \mathrm{mS} / \mathrm{cm}$; current density for Al-Al electrode pairs: $100 \mathrm{~A} / \mathrm{m} 2$; current density for Fe-Fe electrode pairs: $50 \mathrm{~A} / \mathrm{m} 2$; influent COD: $23,520 \mathrm{mg} / \mathrm{L}$; influent total phenol: $1,668 \mathrm{mg} / \mathrm{L}$; reaction volume: $250 \mathrm{~mL}$; stirring rate: $300 \mathrm{rpm}$; temperature: $25 \pm 1^{\circ} \mathrm{C}$ ) 

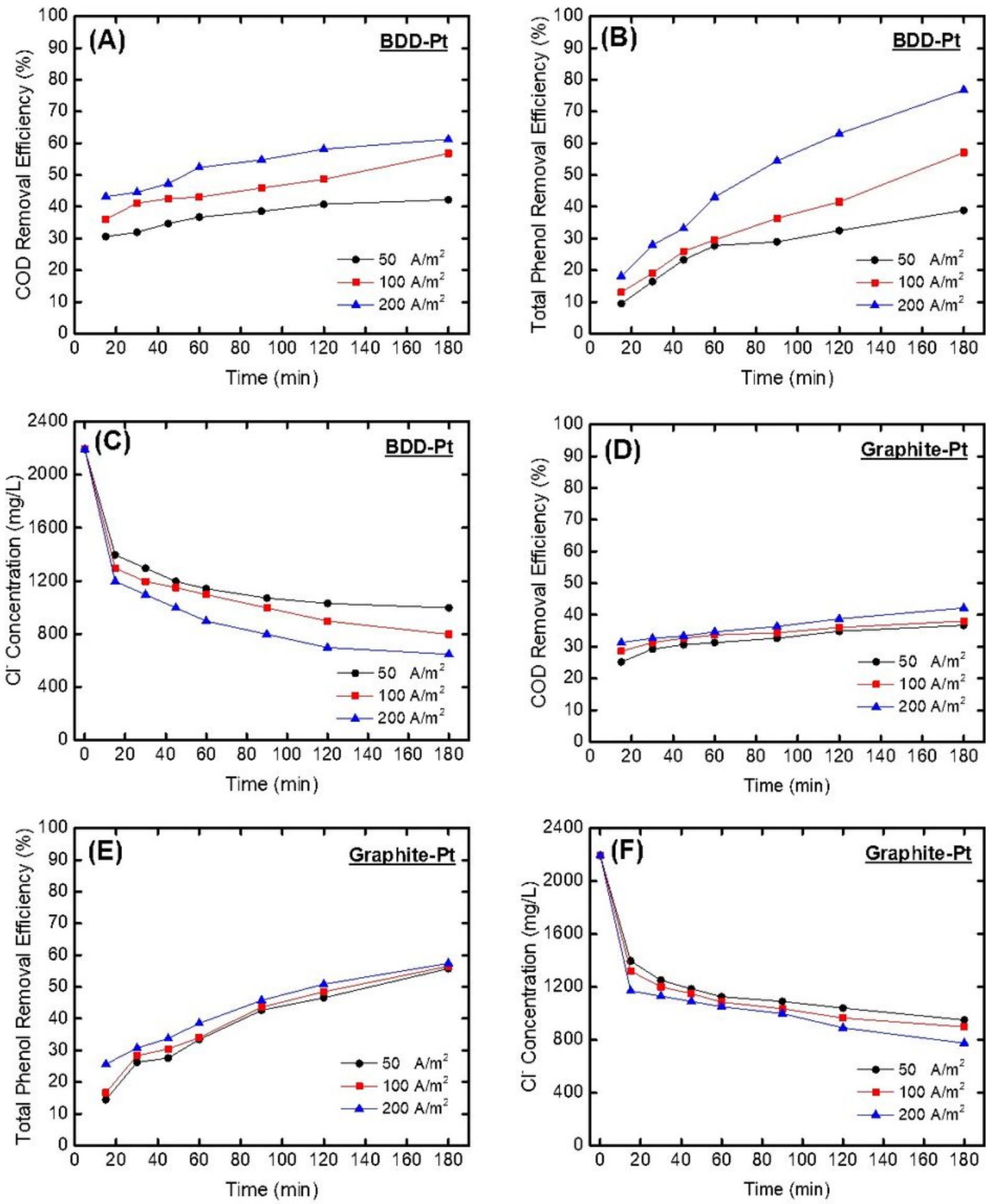

\section{Figure 5}

The effect of current density on (A) COD removal efficiency for BDD-Pt electrode pairs, (B) Total phenol removal efficiency for BDD-Pt electrode pairs, (C) Chloride concentration in the solution for BDD-Pt electrode pairs, (D) COD removal efficiency for graphite-Pt electrode pairs, (D) Total phenol removal efficiency for graphite-Pt electrode pairs, (F) Chloride concentration in the solution for graphite-Pt electrode pairs (Experimental conditions: Conductivity: 5.9 mS/cm; initial pH: 4.3; influent COD: 23,520 
mg/L; influent total phenol: 1,668 mg/L; influent Cl- concentration: 2,193 mg/L; electrode distance: $2 \mathrm{~cm}$; reaction volume: $250 \mathrm{~mL}$; stirring rate: $300 \mathrm{rpm}$; temperature: $25 \pm 1^{\circ} \mathrm{C}$ )
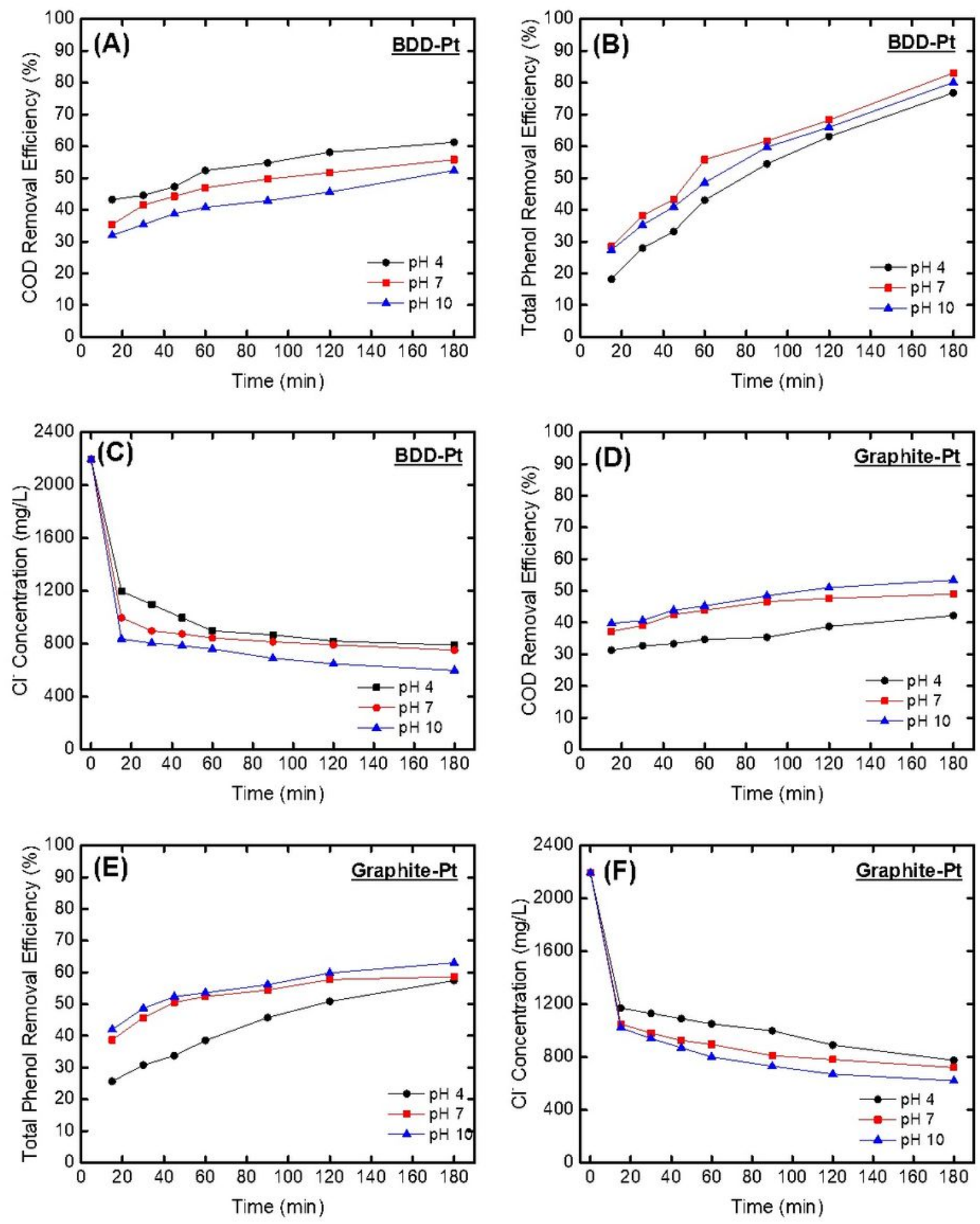

Figure 6

The effect of solution $\mathrm{pH}$ on (A) COD removal efficiency for BDD-Pt electrode pairs, (B) Total phenol removal efficiency for BDD-Pt electrode pairs, (C) Chloride concentration in the solution for BDD-Pt electrode pairs, (D) COD removal efficiency for graphite-Pt electrode pairs, (D) Total phenol removal 
efficiency for graphite-Pt electrode pairs, (F) Chloride concentration in the solution for graphite-Pt electrode pairs (Experimental conditions: Conductivity: $5.9 \mathrm{mS} / \mathrm{cm}$; current density: $200 \mathrm{~A} / \mathrm{m} 2$; influent COD: $23,520 \mathrm{mg} / \mathrm{L}$; influent total phenol: 1,668 mg/L; influent Cl- concentration: 2,193 mg/L; electrode distance: $2 \mathrm{~cm}$; reaction volume: $250 \mathrm{~mL}$; stirring rate: $300 \mathrm{rpm}$; temperature: $25 \pm 1{ }^{\circ} \mathrm{C}$ )
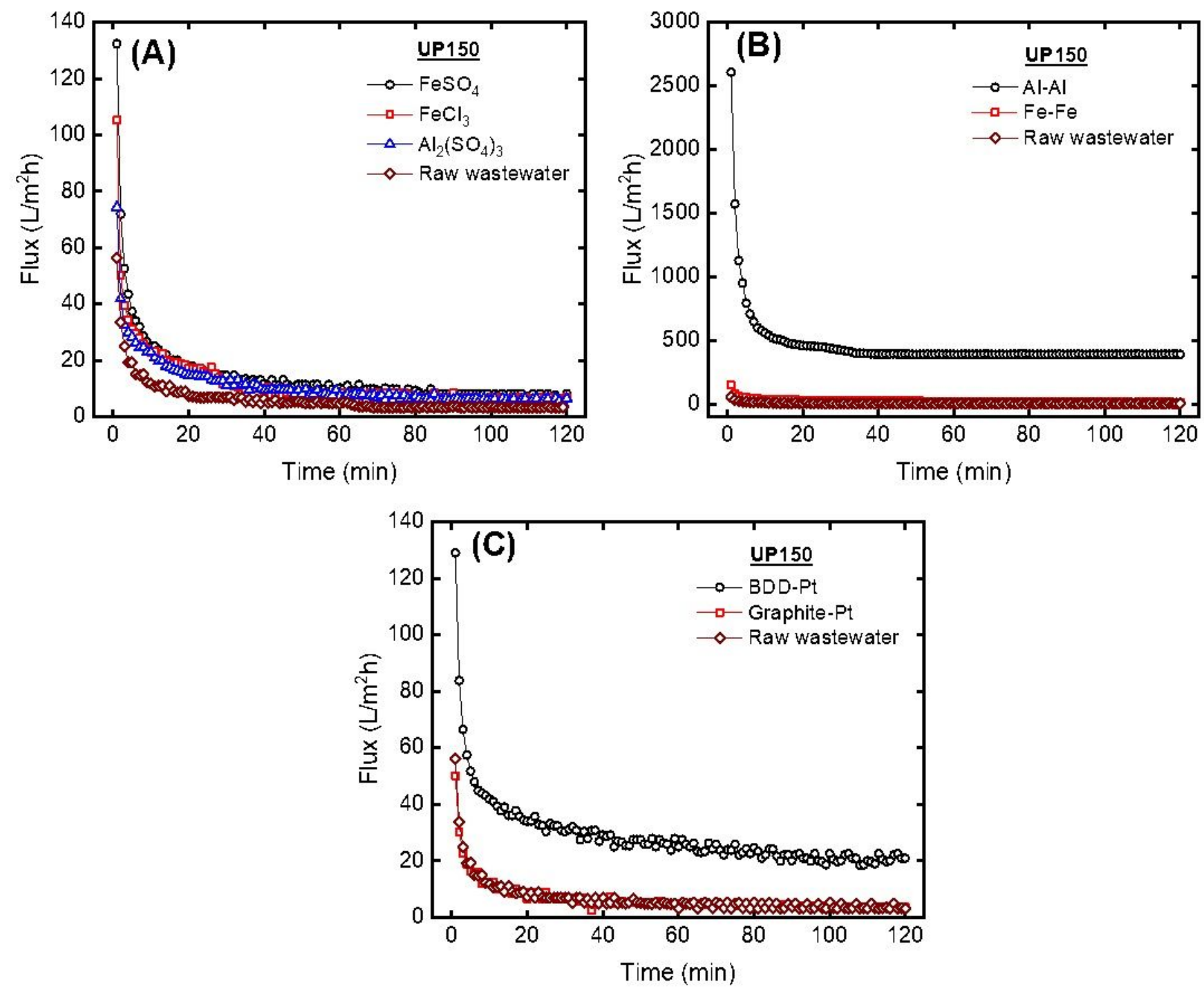

Figure 7

The effect of pre-treatment method on UP150 flux (Experimental conditions: $\Delta \mathrm{P}: 5 \mathrm{bar} ; \mathrm{pH}: 6$ ). 

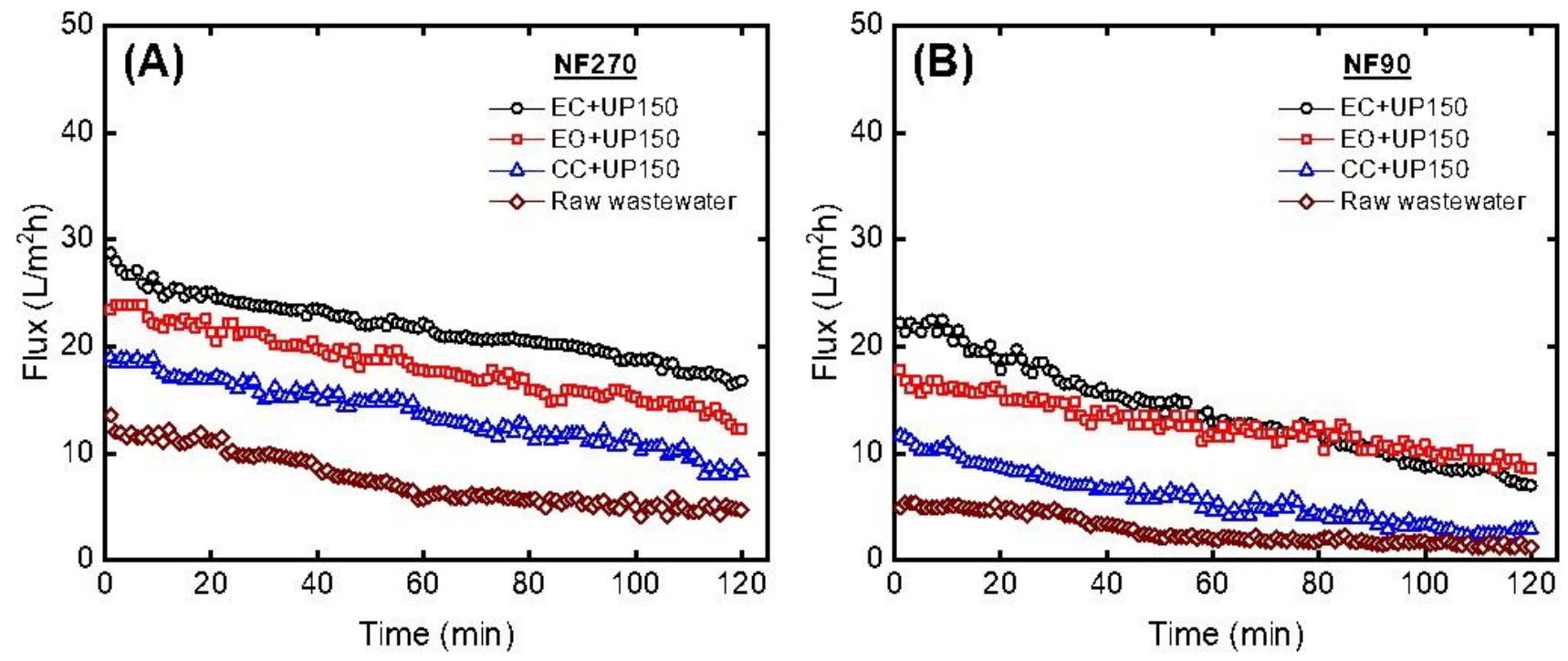

Figure 8

The effect of pre-treatment method on (A) NF270 flux ( $\triangle \mathrm{P}: 5$ bar) and (B) NF90 ( $\triangle \mathrm{P}: 10$ bar) at pH: 6 

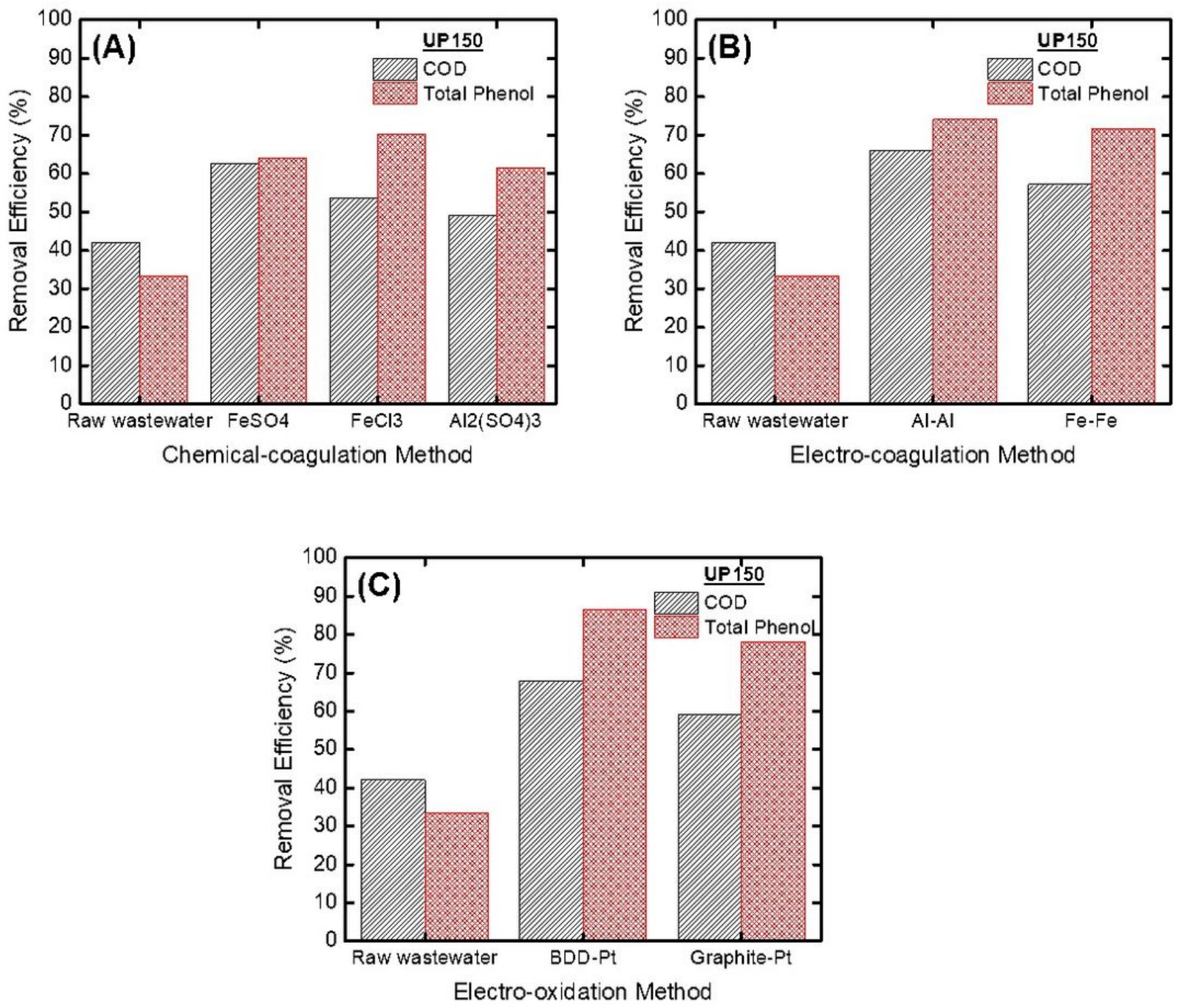

Figure 9

The effects of (A) chemical coagulation, (B) electrocoagulation, (C) electrooxidation pretreatment methods on the efficiency of COD and total phenol removal in the UP150 membrane permeate stream (Experimental conditions: Operating pressure: $\triangle \mathrm{P}: 5$ bar; feed stream: $\mathrm{pH}: 6$ ) 

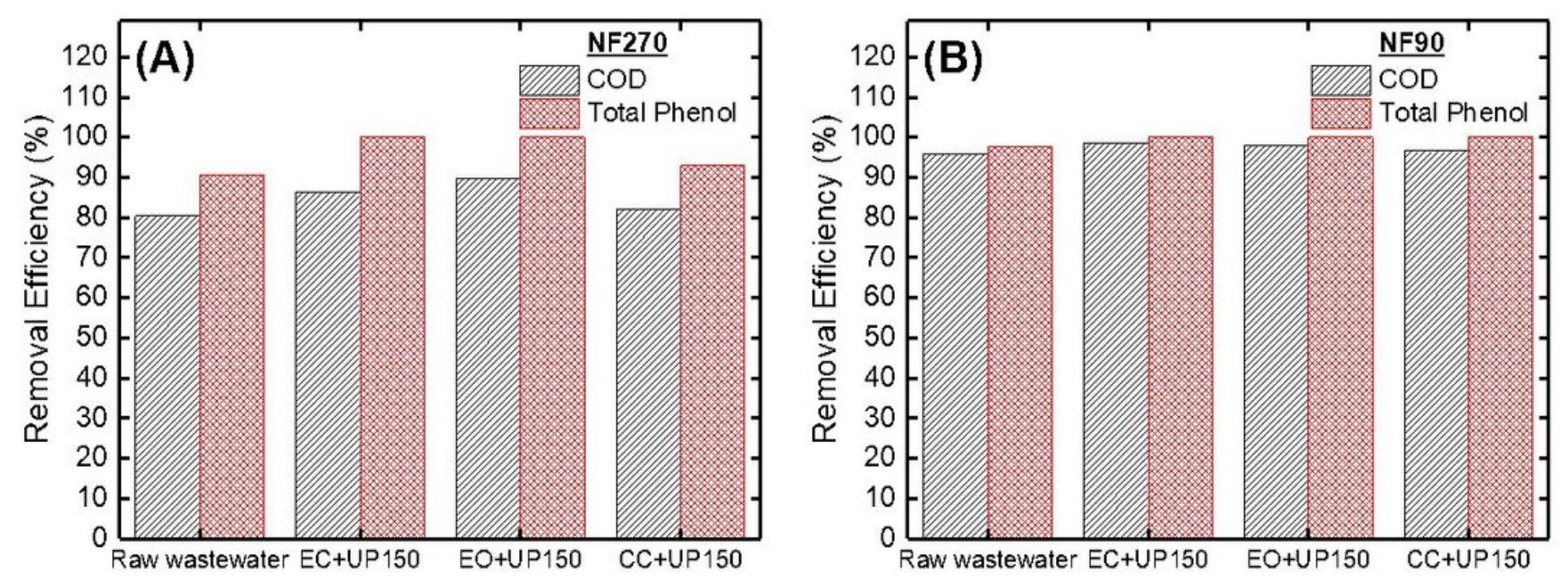

\section{Figure 10}

Effect of pretreatment methods on COD and TF removal efficiency in NF270 (A) and NF90 (B) membrane permeate stream, (Experimental conditions: Operating pressure: $\triangle \mathrm{P}: 5$ bar for NF270 membrane and $\triangle \mathrm{P}$ : 10 bar for NF90 membrane; $\mathrm{pH}: 6$ ) 